From their microscopic appearance, a high proportion of the isolated cells are viable. Further evidence for viability is provided in the capacity of isolated cells prepared from infected tissue to support the multiplication of tobacco mosaic virus when incubated. To date, the synthesis of virus protein can be demonstrated only in an intact cell. More. over, when isolated virus-infected cells were incubated in the presence of a radioactive amino-acid (glycine1. ${ }^{14} \mathrm{C}$ or DL-leucine-1-14 $\mathrm{C}$ ), the amino-acid was incorporated into the protein of the virus. In previous studies with tobacco mosaic virus, incorporation into virus protein was demonstrated only with intact leaf tissue and not in homogenized preparations of a cell-free nature ${ }^{2,3}$, although these cell-free systems were active for the incorporation of radioactive amino-acids into proteins other than the virus. At a later date, I shall report in detail my studies of tobacco mosaic virus synthesis in isolated leaf cells.

To test the general applicability of the method, an ad hoc assortment of leaves of 12 species of plants was tried. Of these, Nicotiana glutinosa, Datura stramonium and potato yielded cells which compared favourably both in yield and appearance with those of N. tabacum; Chenopodium amaranticolor, Quercus borealis and Crotelaria spectabilis gave relatively few cells of good appearance; corn and Ginkgo biloba yielded no cells at all. There was good cell production from leaves of two species of Prunus (a peach and a cherry), cucumber and Magnotia sp., but the cells looked injured, being reminiscent of the appearance of the tobacco leaf cells prepared under conditions of either low $p \mathrm{H}$ or unfavourable sucrose concentration.

These studies were initiated at the Commonwealth Scientific and Industrial Research Organization, Division of Plant Industry, Canberra. At the University of Missouri, partial support was derived from a grant of the Herman Frasch Foundation.

Department of Horticulture,

\section{Mriton ZaitLiN}

University of Missouri,

Columbia, Missouri. June 12.

1 Chayen, J., Nature, 170, 1070 (1952).

Stephenson, M. L., Thimann, K. V., and Zamecnik, P. C., Arch. Biochem. Biophys., 65, 194 (1956)
Boardman, N. K., and Zaitlin, M., Virology, B, 758 (1958).

\section{Effect on the Groundnut of Variations in Supply of Potassium, Calcium and Magnesium}

Groundnuts (var. Philippine Pink) were grown in pots using a typically infertile local soil with the primary object of studying Prof. M. V. Homès's "Method of Systematic Variations"1 for the determination of major element requirements. With the exception of the controls, plants were supplied with $100 \mathrm{mgm}$. equivalents of various proportions of potassium, calcium and magnesium, $100 \mathrm{mgm}$. equivalents of a good fixed ratio of nitrate, sulphate and phosphate, and micronutrients at levels known to be suitable for many plants in sand culture ${ }^{2}$

There are three distinct optimum mixtures for the production of 'tops', shell and kernels (Fig. 1). There is a depressive effect of some mixtures on quantity and quality of seed production while the controls produced good-quality 'nuts'. The effect of shortage of calcium on groundnuts is well known particularly in the United States, while the effect of a

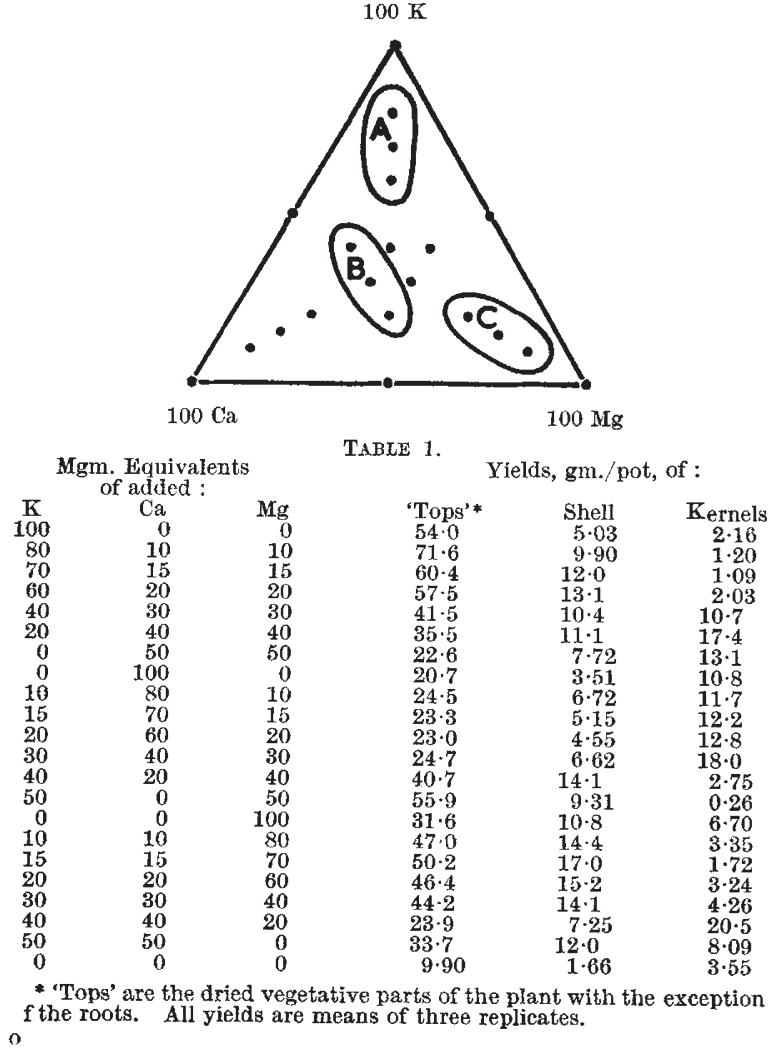

relative excess of potassium is known here in Gambia ; $200 \mathrm{lb}$./acre of potassium chloride can result in an increase in groundnut hay yield of up to 30 per cent with a simultaneous depression in 'nut' yield of 14 per cent. The apparent importance of magnesium in groundnut pericarp formation was unexpected, as was the completely different behaviour from tomatoes grown in similar conditions; the best ratio of potassium:calcium:magnesium (as equivalents) for tomato fruit production was approximately $40: 12 \cdot 5$ : 47.5 , while the optimum for vegetative growth was $35: 40: 25$.

This note is published with the permission of the Government of the Gambia.

Department of Agriculture,

R. COMBer Gambia.

I Homes, M. V., Soits and Fert., 18, 1,101 (1955)

Hewitt, E. J., 'Sand and Water Culture Methods used in the study 1952).

\section{Prefreezing as a Method enabling Animals to survive Freezing at an Extremely Low Temperature}

IN a previous paper it was demonstrated that, after sufficient extracellular freezing, some intact insects could survive freezing in liquid oxygen without any antifreeze agent1. This might be a method for keeping an entire organism alive at extremely low temperatures, provided that it is sufficiently frostresistant. Some work along these lines has been carried out in our laboratory. In plant tissues, Sakai has already successfully applied the method to 